\title{
Effect of Nickle Nanoparticles Solution on Staphylococcus aureus Contaminated Open Wounds Healing in Mice
}

\author{
Hala Mohammed Majeed ${ }^{1 *}$ (D), Siham Agmee Wadee ${ }^{2}$ and Waseem Ali Hasan ${ }^{2}$ \\ ${ }^{1}$ Department of Basic sciences, College of Medicine/ Ibn Sina University of Medicine and Pharmaceutical Sciences, \\ Baghdad, Iraq. \\ ${ }^{2}$ Department of Pharmacology and Biochemisty, College of Veterinary Medicine, University of Tikrit, Iraq.
}

\begin{abstract}
The bacteria have been noted as the main cause of late wound healing. The greatest common pathogen causing the wound contaminations is Staphylococcus aureus. The current study was carried out to isolate and diagnose the staphylococcus aureus which causes of open wound inflammation after surgery in mice process and to study the effect of nickle nanoparticles solution on bacterial isolated and evaluating the molecular and pathological techniques. The study included the collection of 60 cotton swabs from the Office of the Consultant of the Faculty of Veterinary Medicine - Tikrit University and from the external veterinary clinics (from November 2018 to March 2019) from the areas of contaminated wounds or inflamed after surgery. The results of the laboratory cultural of 60 cotton swabs used showed to isolated 50(83.3\%) Staphylococcus aureus isolated. And all bacterial isolates were resistant to Doxycycline hydrochloride, Penicillin, CO-Trimoxazole, Ciprofloxacin, Cephalosporin and Penicillin. The study showed that the NFNPS used to inhibit the growth of bacterial isolated by using different concentrations the MBC killer concentration was $256 \mu \mathrm{g} / \mathrm{L}$ and the lowest inhibitory concentration to Staphylococcus aureus was MIC 64 microgram / L). Molecular studies included the observation of the most important molecular changes at the level of DNA prior to and treatment with nanoparticles. Many variations were observed on the studied bacterial isolated Including the appearance and disappearance of DNA and its different numbers when treated with nanoparticles. As for the results of the histopathological, it was found that the injury of mice with Staphylococcus aureus antibiotic resistance emerged after about five days and the symptoms were heat, redness and swelling of the skin and the release of yellow and green purulent secretions from the place of injury. When treated mice infected with nanoparticles and antibiotics together the time of the healing was faster than the time of the healing of nanoparticles treated only.
\end{abstract}

Keywords: Effect, Nickle, nanoparticles, staphylococcus aureus, Contaminated wounds, healing, mice

*Correspondence: m.hala17@yahoo.com

(Received: February 11, 2020; accepted: March 11, 2020)

Citation: Majeed HM, Wadee SA, Hasan WA, Effect of Nickle Nanoparticles Solution on Staphylococcus aureus Contaminated open wounds healing in mice, J. Pure Appl. Microbiol., 2020; 14(4):2637-2648. doi: 10.22207/JPAM.14.4.40

(C) The Author(s) 2020. Open Access. This article is distributed under the terms of the Creative Commons Attribution 4.0 International License which permits unrestricted use, sharing, distribution, and reproduction in any medium, provided you give appropriate credit to the original author(s) and the source, provide a link to the Creative Commons license, and indicate if changes were made. 


\section{INTRODUCTION}

Wound infection is a frequent problematic. Due to entrance of the bacteria through open skin. These bacteria delay healing and yield symbol and symptoms ${ }^{1}$.

Wound infection in care for increasing the treatment cost, length of hospital delay and significant morbidity and mortality. Despite the practical advance in infection control and surgical practice, Site surface infection (SSI) still continue to be a major problematic, even in hospitals with most recent facilities ${ }^{2}$. These infection are usually cause by exogenous and/or endogenous bacteria that arrive the working wound either through the surgery (primary infection) or after the surgery (secondary infection). Primary infection are usually more serious, appear within five to seven days of surgery ${ }^{3}$. Common of SSIs are uncomplicated connecting only skin and subcutaneous tissue but occasionally can expansion to necrotizing infection. The common demonstration of infected surgical wound can be describe by hurt, tenderness, warmth, erythema, enlargement and pus configuration ${ }^{4,5}$.

Despite efforts to establish infection and well understanding of sepsis, wound contamination is immobile a clinical problematic and some infection in clean injuries still remain unexplained ${ }^{6}$. In many SSIs, The bacteria in charge for producing SSI are Staph aureus; Staphy epidermidis; Gram negative bacilli; Streptococcus spp; Enterococci; and $\mathrm{Cl}$. perfringens. More than $50 \%$ of SSI is cause by $S$. aureus because it is highly dangerous. Staphylococcus epidermidis is fewer virulent and usually causes SSI only in patients who are previously immune compromised ${ }^{7}$.

Several organisms can cause wound infectivity. For the treatment of contamination a great number of antibiotics are used. Both extensive spectrum and thin spectrum antibiotics are current nowadays. It is perfect to give appropriate antibiotic after culture and sensitivity of the wound swab, pus or contaminated skin. unluckily this practice is unusual between the physicians especially of the developing countries. Improper and irrational use of antibiotics and genetic and non-genetic drug resistant machine of bacteria lead to drug resistance ${ }^{8}$.

Nano-sized particle to win this battle and to overcome this frightening condition of bacterial resistance to antibiotics, the search and detection of alternative means against these microbes is only way forward to survive. Metals based nanoparticles and analysis of their antimicrobial activity could be one of such alternative. Many studies are being done to prove the structural and chemical effect of various metals Nano-complexes to determine an alternation of the drugs which used against bacteria ${ }^{9}$. Nickel is also among those material which can be used for antimicrobial activity so the synthesis, categorization and antimicrobial presentation of Nickel based nanoparticles of large importance. Owing to high surface region to size ratio and quantum confinement effect are consider promising candidates for Nano devices of fresh Objective

The objective of theses study isolation and identification of Staphylococcus aureus from Contaminated open wounds and study effected of Nickle Nanoparticles on bacterial isolated by using histological and molecular techniques

\section{MATERIAL AND CLINICAL STUDY Nickel Ferrite $\left(\mathrm{NiFe}_{2} \mathrm{O}_{4}\right.$ ) Nan particles (NFNPS)} Obtained from the College of Science, Department of Chemistry and preparation manner Sol-Gel Auto Combustion Method ${ }^{11}$.

\section{Animals Experiments}

In this study, 42 mice, Mus musculus were obtained from the veterinary home of the college of Veterinary Medicine. All six mice hatches were placed in a plastic cage, the dimensions of the cage were $8 \times 15 \times 30 \mathrm{~cm}$, and the cages were sprayed with wood and The temperature of the room was about $22 \pm 25$, The animals were fed on the blackberry consisting of $35 \%$ yellow corn, $20 \%$ soy bean, $10 \%$ animal protein, $1 \%$ dried milk and $1 \%$ of both vitamins and mineral salts.

\section{Samples Collection}

Collected 60 swabs from mice were taken from Surgical wound contamination by sterile cotton swabs and transported to laboratory as soon as possible in disinfected Brain heart infusion broth that incubated at 37CO for at least 24-28 hours to rising probability of isolation ${ }^{12}$.

Isolation and Identification of $\mathbf{4 2}$ white mice were used after confirm their

All Swab specimens were cultured into Brain heart infusion broth and then onto mannitol 
salt agar incubated for overnight at $37^{\circ} \mathrm{C}$ for $24 \mathrm{hrs}^{12}$.

\section{Biochemical test \\ Catalase test}

Catalase and coagulase tests use distinguish isolated bacterial consistent with method describe by ${ }^{13}$.

\section{Oxidase Test}

Cytochrome oxidase is the last enzyme in the electron transport chain of microbial cell inhalation. It oxidizes cytochrome $\mathrm{C}$, the electron transport atom and decrease oxygen to form water. If oxidase was present in the colony, it would oxidize the substance and the colony on the filter paper would turn dark blue within one minute. A negative oxidase test resulted in no color alteration of the smear (Cowan and Steel (1993) ${ }^{13}$.

\section{Urease test}

Certain microorganisms have enzymes called ureases which are capable of hydrolyzing urea to produce alkaline ammonia $\left(\mathrm{NH}_{4}\right)$. The tubes were inoculate with the tasters in question and allowable to incubate at $37^{\circ} \mathrm{C}$ for 24 hours, at which finish tests were at first read. Pinkish or red tubes were interpret as positive. Yellow tubes negative ${ }^{10}$.

\section{Indole, MR and VP tests}

Differentiate the isolation bacterial described by (Cowan and Steel (1993) ${ }^{13}$.

\section{Citrate utilization test}

Citrate test is used to recognize if an organism is able of utilizing citrate as a sole carbon source or not. Citrate medium contain sodium citrate as the only basis of carbon and ammonium phosphate as the only basis of nitrogen .bacteria which have citrate-permease can transfer citrate in to the cell and create pyruvate and show a color alter from green to blue. incubation ${ }^{14}$.

\section{Fermentation test}

This test used to differentiate between types of the bacterial which capacity of ferment a broad group from sugars and others ferment only a few described by (Ryan and Ray (2004) ${ }^{15}$.

Microbial Identification Using The Biomerieux Vitek $^{\circledR} 2$ System

This system is used to identify bacterial isolates after being established by first biochemical tests. The system consists of 64-hole Cassette and 64-hole Reagent Cards, each in its place of the base material or medium for testing, plastic tubes in addition to the Densi Chek instrument and the input and output units ${ }^{16}$.

\section{Antimicrobial sensitivity test}

In vitro antibiotic sensitivity test (KirbyBaur disc diffusion) method was accepted out in organize to distinguish the most valued drugs for treatment in the study county. A loop full of colony from the growing of isolate was transmission to the nutrient broth in tubes and incubated at $37^{\circ} \mathrm{C}$ for $5 \mathrm{~h}$. Mueller-Hinton agar which was used as plating medium was inoculated with broth (bacterial suspension) by using cotton swab. Then antibiotic impregnate paper disc were apply and broke onto the plate with forceps. Plates were incubated at $37^{\circ} \mathrm{C}$ for $18 \mathrm{~h}$. The diameters of zones of growth inhibition were measured in millimeter and interpret as sensitive, middle and resistant to different antibiotics ${ }^{17}$.

Preparation of the concentrations of the nanoparticle solution

The least bactericidal concentration (MBC) is the lowest concentration of nanoparticle solution an required to kill a exacting bacterium. It can be determined from broth dilution minimum inhibitory concentration (MIC) tests by sub culturing to agar plates that do not have the test agent. The MBC is familiar by determining the lowest concentration of antibacterial agent that decrease the chance of the initial bacterial inoculums by $\geq 99.9 \%{ }^{18}$.

\section{Extraction of genetic material}

Genomic DNA extraction From an overnight blood agar culture, pure colony was sub cultured in $10 \mathrm{ml}$ of bh broth overnight, in aerobic conditions, at $37^{\circ} \mathrm{C}$ before extraction of total DNA, genomic DNA from the growth cultures was extracted and purified by using the manufacturer protocol (Geneaid "Presto", Korea). The integrity of genomic DNA were established by agarose gel electrophoresis with $1 \%$ concentration for one hour at 70 volt and the nanodrop spectrophotometer device (NAS-99) was used to calculate the DNA attentiveness and cleanliness (ratio of absorbance at $260 \mathrm{~nm} /$ absorption at 280 $\mathrm{nm}^{19}$.

\section{RAPD situations}

PCR reaction were perform with three salable 10- mer primers (Invitrogen) with the following $5^{\prime}-3^{\prime}$ sequences: (OPH-14) 5-ACCAGGTTGG -3 (OPO-11) 5-GACAGGAGGT 
-3 and(OPP-4) 5-GTGTCTCAGG -3.Optimum conditions for RAPD study were determined by the maximum sum of fragments and careful bands(20). Expermintal design

42 white mice were used after confirm their security from the diseases and were divided into five groups and each group consists of 6 mice except (groups IIII and V each another 12 mice) were distributed as follows:-

Group one (control group) - 6 mice were treated with distilled water only.

Group II (infection groups) - 6 Mice were infected with staphylococcus aureus by (1) ml skin Scratched.

Group III - 6Mice were diseased with staphy. aureus with skin Injured. and treated with (CFNPS)carrying with Vaseline.

Group IIII- 12Mice were ill with staph. aureus and treated with antibiotics(Doxycycline hydrochloride and Ciprofloxacin).

GroupV - 12 Mice were infected with staphyl. aureus and treated with antibiotics

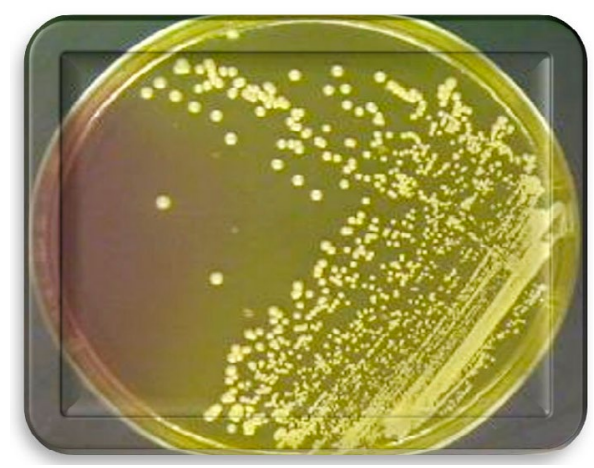

Fig. 1. Staphylococcus aureus on mannitol salt agar.

Table 1. Biochemical test of Staphylococcus aureus
(Doxycycline hydrochloride and Ciprofloxacin) and nanoparticles.

\section{RESULTS}

Result showed 50(83.3\%)strain belong Staphylococcus aureus. The growth colonies characteristic by following characters.

\section{Cultural characteristic}

The bacterial growth aerobic at $37^{\circ} \mathrm{C}$ for $24 \mathrm{hr}$ after incubation on the culture media, the colonies appearance golden yellow color on surface of Mannitol salt agar as shown Fig. 1.

\section{Staining}

Bacterial isolated appearance purple when staining gram stain.

\section{Biochemical test}

Bacterial isolated given positive result to catalase, citrate utilization test, sugar fermentation (sucrose, glucose) while negative results to indole, methyl red, VP and sorbitol sugar.

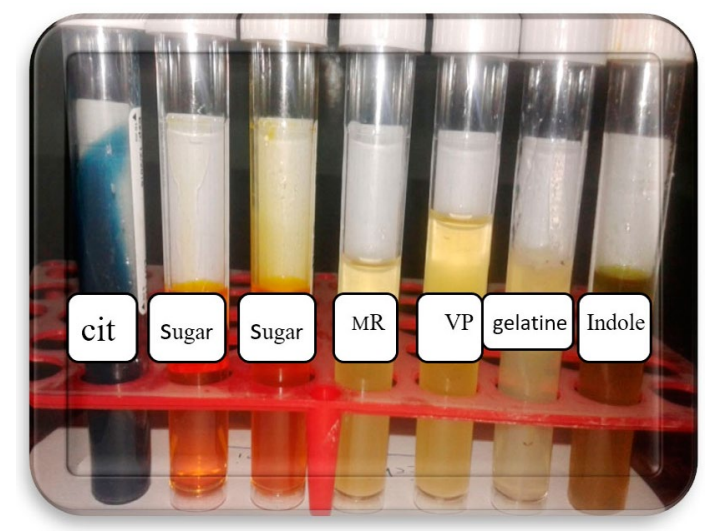

Fig. 2. Biochemical test of Staphylococcus aureus

\begin{tabular}{lcccccccc}
\hline $\begin{array}{l}\text { Bacterial } \\
\text { isolated }\end{array}$ & $\begin{array}{c}\text { Oxidase } \\
\text { test }\end{array}$ & $\begin{array}{c}\text { Catalase } \\
\text { test }\end{array}$ & $\begin{array}{c}\text { Indole } \\
\text { Methyl } \\
\text { red }\end{array}$ & $\begin{array}{c}\text { Voges } \\
\text { proskours }\end{array}$ & $\begin{array}{c}\text { Citrate } \\
\text { test }\end{array}$ & glucose sucrose Sorbitol \\
\hline S. aureus. & - & + & - & - & - & + & + & + \\
\hline
\end{tabular}

Table 2. Antibiotic Susceptibility Test results of bacterial isolates

\begin{tabular}{lccccc}
\hline $\begin{array}{l}\text { Isolate } \\
\text { bacteria }\end{array}$ & $\begin{array}{c}\text { Doxycycline } \\
\text { hydrochloride }\end{array}$ & CO-Trimoxazole & Ciprofloxacin & Cephalosporin & Penicillin \\
\hline S. aureus & Resistant & Resistant & Resistant & Resistant & Resistant \\
\hline Journal of Pure and Applied Microbiology & & 2640 & www.microbiologyjournal.org
\end{tabular}




\section{Antibiotic Susceptibility Test}

Study sensitivity bacterial isolated toward 5 Antibiotics are Doxycycline hydrochloride, CO-Trimoxazole, Penicillin, Cephalosporin and Ciprofloxacin.

The result showed all bacterial isolated to Staphylococcus aureus were resistant to all antibiotics used in study as showed in Table (2).

Effect of Nanoparticle Solution (NFNPS) on Staphylococcus aureus

Results of the study showed impact of nanoparticles (NFNPS) used has the potential to inhibit the growth of bacterial isolates using different concentrations. MIC $(64 \mu \mathrm{g} / \mathrm{ml})$ and MBC $(256 \mu \mathrm{g} / \mathrm{ml})$ to Staphylococcus aureus as shown in Table 3.

\section{DNA Isolation}

DNA was isolated from resistant Staphylococcus aureus by using the method described ${ }^{21}$ and was then transplanted onto agarose gel as shown in the Fig. 3.

\section{Results of RAPD-PCR interactions}

The results showed the Differences in DNA were recorded between samples studied through
The presence of DNA bunds and multiplying their absence.

Difference in molecular weights between bands.

Difference in number of bands.

The differences in the intensity of bands shine on.

These results were obtained after several experiments to reach optimal interaction conditions, where the reaction components were controlled (dNTPS, Taq DNA polymerase, $\mathrm{MgCl}_{2}$, DNA concentration as well as the concentration of the same primers, the suitability of the program on the thermo cycler and the pipette resolution used), This led to get products doubled Clear and repeatable, As the RAPD Markers are sensitive to any change in the components of their reactions And the conditions surrounding the reaction where it is one of the reactions that are characterized by the difficulty of replay and get the same result. Therefore, RAPD interactions for each user's primers were repeated once as in the Fig. 4.

There are many variations in the different primers, the nanoparticles have a clear effect

Table 3. Effect of MIC and MBC for nanoparticles (NFNPS) on Staphylococcus aureus

\begin{tabular}{lcccccccccccccc}
\hline $\begin{array}{l}\text { Bacterial } \\
\text { isolates }\end{array}$ & $\begin{array}{c}\text { Nanoparticle } \\
\text { NFNPS }\end{array}$ & 1024 & 512 & 265 & 128 & 64 & 32 & 16 & 8 & 4 & 2 & 1 & 0 \\
\hline \multirow{2}{*}{ S. aureus } & MIC & - & - & - & - & 0 & + & + & + & + & + & + & - \\
& MBC & - & - & - & + & + & + & + & + & + & + & + & - \\
\hline
\end{tabular}

MIC=No growth(-), turbidity(+)and (0) control(Muller-Hinton Broth + Antibiotic).MBC=growth(+) and sterile(-).

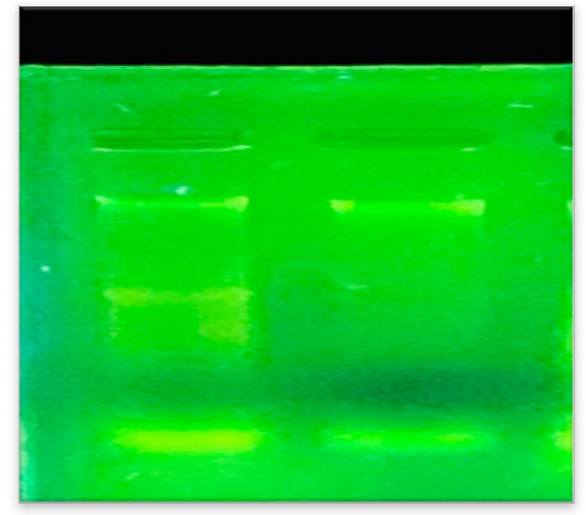

Fig. 3. Genomic DNA Staphylococcus aureus on agarose gel $1 \%$.
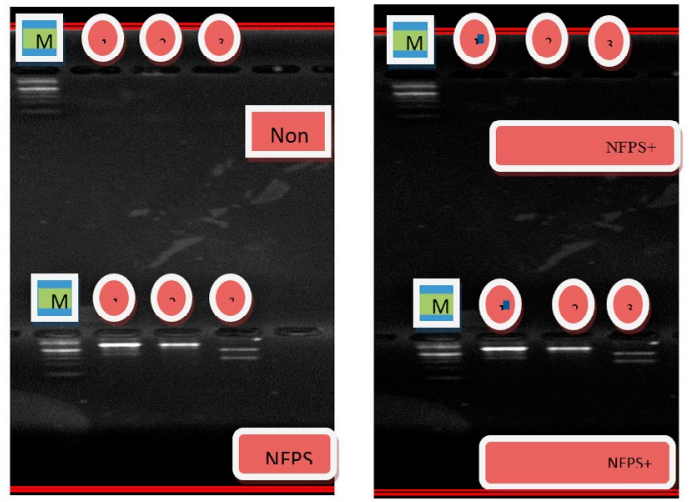

Fig. 4. DNA bands for Staphylococcus aureus before and after treatment with nanoparticles and antibiotics 
on the bacteria. Some of them have caused full mutagen of the gene, some of which have the most recent mutations in the appearance and disappearance of certain bands and differences in bands locations, note in the first, second and third pimers of the Staphylococcus aureus difference in the size and location of the beams Nanoparticles also have the effect of increasing the efficiency of antimicrobial agents by completely hiding the gene or causing mutations this variation in initiator link sites with DNA and the distance between these sites may be created due to mutations that have been cases of deletion, substitution and addition leading to a change in the order of rules complementary to the initiator sequence.

Results of the Experiment mice treatment with nanoparticles and antibiotics

The results of the experiment infection of the mice with Staphylococcus aureus showed symptoms of inflammation after approximately five days. The symptoms were high fever, redness, painful, swollen, and yellow or green ulcerative ulcers around the surgical site as shown in the Fig. 5.

After the onset of infection and treatment of mice with nanoparticles and antibiotics and according to the groups reported, the results showed that the recovery time of the group treated with antimicrobial and nanoparticles together was faster than the time of recovery of mice treated with nanoparticles only.

\section{Results of Histopathology}

Results show the Histopathology to control skin, the epidermis formed from a thin layer of epithelial cells consisting of 2-3 raw. They are dark and bold especially the surface because of the layer of globins and this layer overlapping at the bottom with the layer under the epidermis,
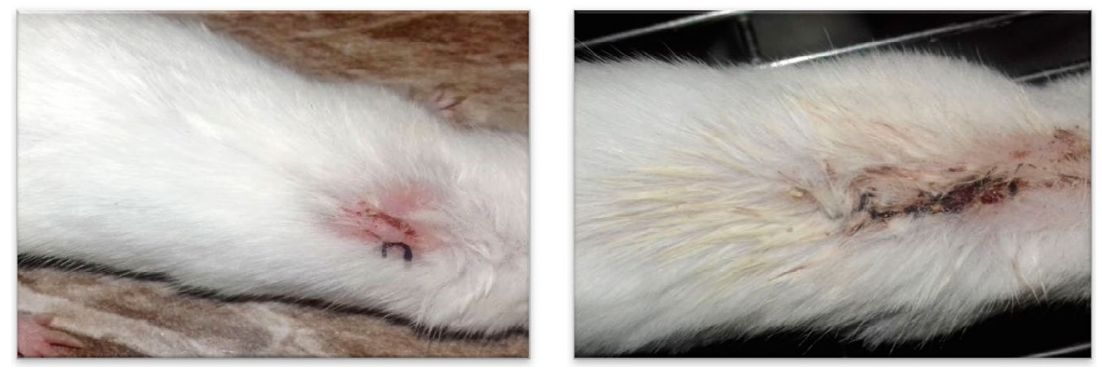

Fig. 5. appearance of symptoms of infection of mice with bacteria

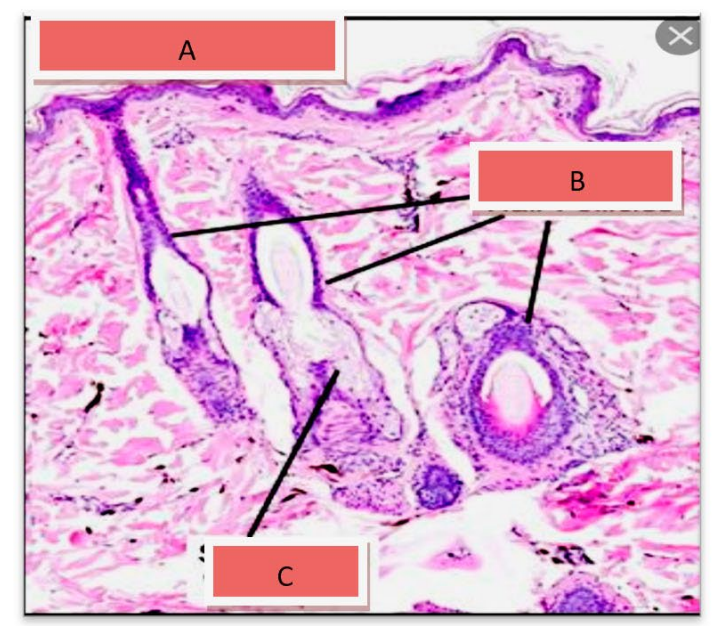

Fig. 6-A. Histological section In the skin

(A) Epidermal surface, (B) Hair Follicles.(C) Sebaceous gland€.(H\&E X 40).

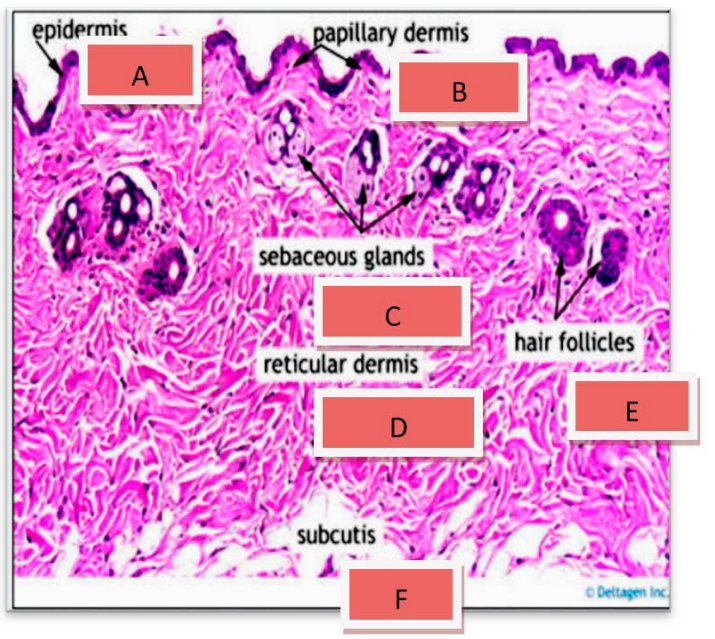

Fig. 6-B. Histological section

(A) Epidermis(B)p apillary dermis, (C) Sebaceous gland.

(D) reticular dermis (F)subcutis(E) Hair Follicles 
which has a fibrous tissue link made of fiber and the presence of the capillaries in this region continued with larger blood vessels in the area below it, The dermis layer contains fibrous fiber bundles and longitudinal sections of the hair follicles that are directed towards the epidermis and outside, in addition to the presence of dense, continuous fatty tissue with the hypodermis layer. The dermis also contains hair follicles and sweat glands as shown in the Fig. 6-A and B.

Results show the Histopathology to infected area Staphylococcus aureus The epidermis was formed by stratified squamous epithelium ,This epithelium was covering by keratin which was appearing breaking down into many fragments

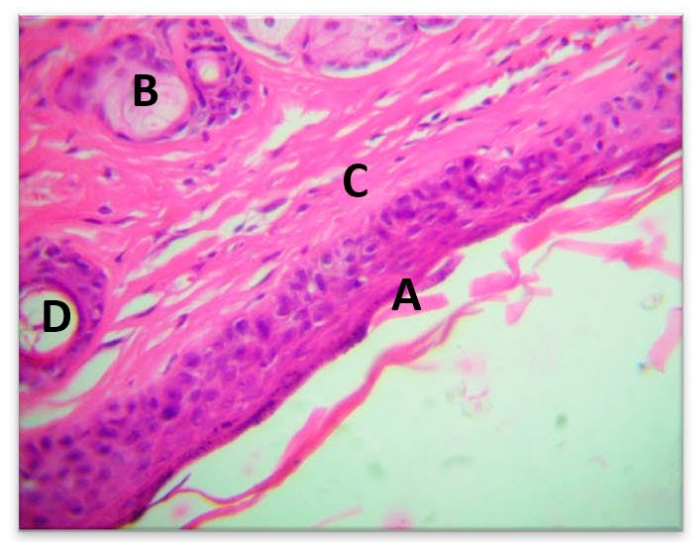

Fig. 7-A. Histological section In Epidermis to infected area Staphylococcus aureus

(A) keratin, (B) Dermis, (C) hair follicle, (D) Sebaceous gland $(H \& E \times 40)$.

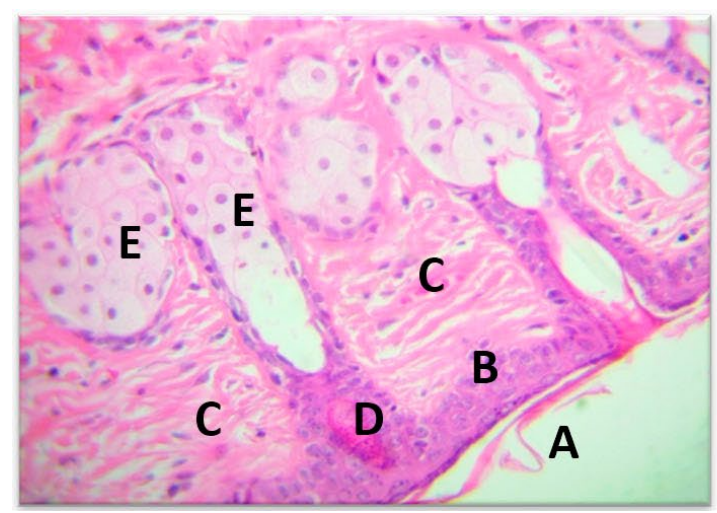

Fig. 8-A. Histological section in Keratin to treated area with nanoparticles to the Staphylococcus aureus A) Hypodermis, (B) Blood congestion, (C) Lymphocytes, (D) (H\&E X 40). scattered above the surface of the epidermis. The dermis was containing dense C.T. and presence of many hair follicles surrounded by a sheath of follicular cortical cells, associated with sebaceous glands (Fig 7-A).

The deepest layer of dermis with hypodermis was containing a dense and great number of inflammatory WBC, with congestion of blood vessels surrounded by lymphocytes and macrophage(Fig. 7-b).

The results of the Histopathology to the treated area with nanoparticles to the Staphylococcus aureus showed, The epidermis was easily detected formed by stratified squamous epithelium with thin strands of keratin covering

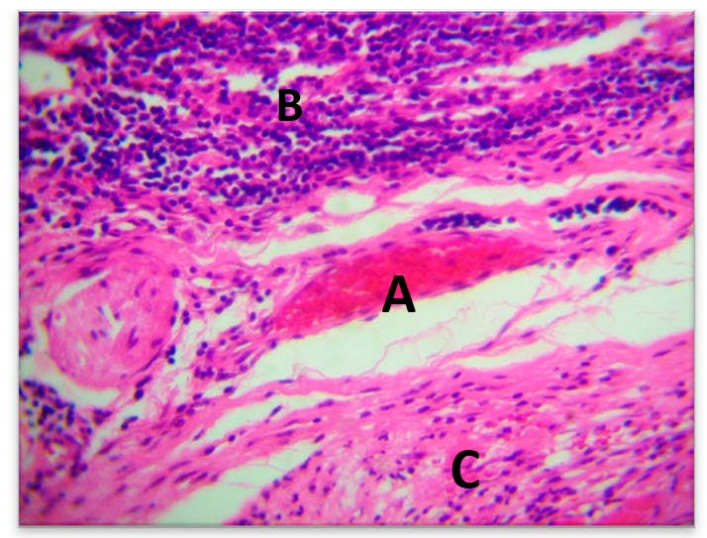

Fig. 7-B. Histological section in dermis to infected area Staphylococcus aureus

(A) Hypodermis with presence of inflammatory cells, (B) congested blood vessel, $(C)(H \& E \times 40)$.

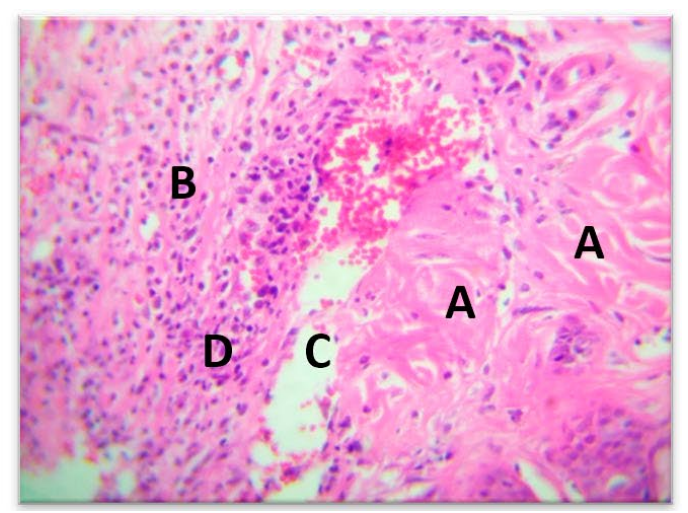

Fig. 8-B. Histological section in Deep of dermis to treated area with nanoparticles to the Staphylococcus aureus (A) Stratifiedsquamous epithelium, (B) Dermis, (C) Hair follicles, (D) Sebaceous gland, (E) (H\&E X 40). 
its surface, this epithelium was seen continuous in certain places with hair follicles and sacs of sebaceous glands. The dermis in between glands and hair follicle was formed by dense C.T. associated with a number of fibroblasts and WBC s (Fig 8-A).

The deepest layers of dermis and the hypodermis was greatly infiltrated by lymphocytes, macrophages and other WBCs, blood congestion was seen in blood vessels also (Fig. 8-B)

The results of the Histopathology to the treated area with nanoparticles and Doxycycline

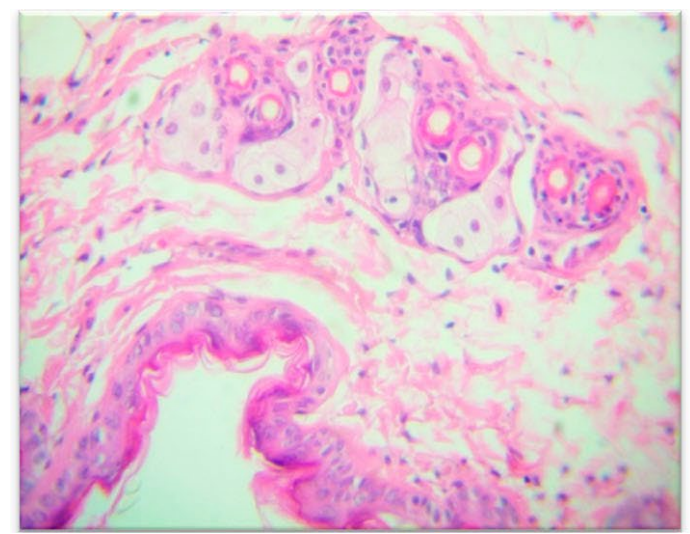

Fig. 9-A. Histological section in Irregular pattern of epidermis treated area with nanoparticles and Doxycycline hydrochloride to Staphylococcus aureus (A) Loose C.T of dermis, (B) Hair follicles, (C)Sebaceous glands, (D) (H\&E X40).

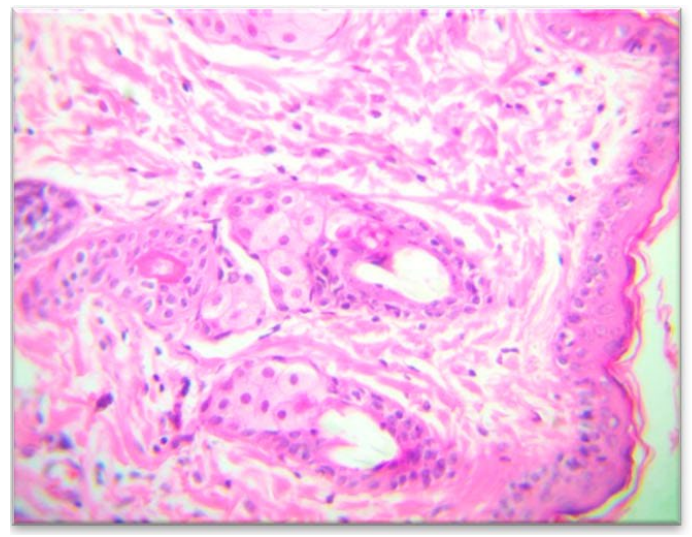

Fig. 10-A. Histological section in Strand of Keratin to the treated area with nanoparticles and Ciprofloxacin to Staphylococcus aureus to Staphylococcus aureus (A) on the surface of epithelium, (B) Dermis with collagen bundles, (C) Hair follicles, (D)Sebaceous glands (E) (H\&E X 40). hydrochloride to Staphylococcus aureus The stratified squamous epithelium was severly corriguated and its surface was covered by keratin. The dermal layer was formed by loose C.T. with WBCs, also there was groups of hair follicles, sebecous glands and weat glands (Fig 9-A).

The sweat glands and hair follicles were passing through the epithelium toward the surface of epidermis (Fig 9-b).

The results of the Histopathology to the treated area with nanoparticles and Ciprofloxacin to Staphylococcus aureus. The stratified squamous

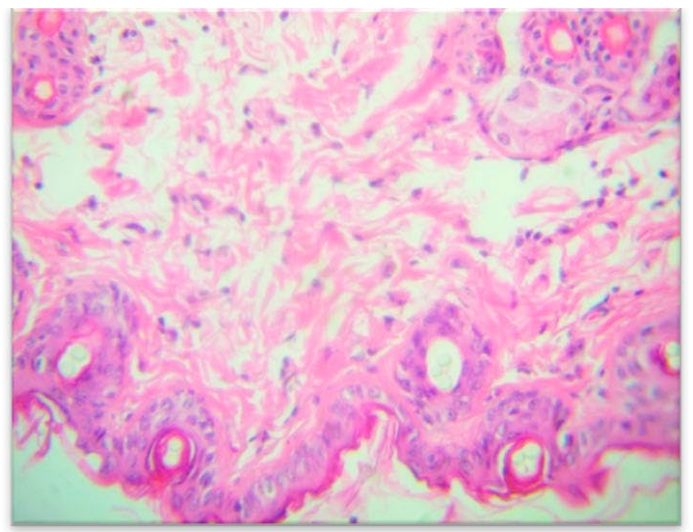

Fig. 9-B. Histological section in Hair follicles passing through the stratified squamous epithelium outside the skin treated area with nanoparticles and Doxycycline hydrochloride to Staphylococcus aureus

(A) Dermis, (B) (H\&E X 40).

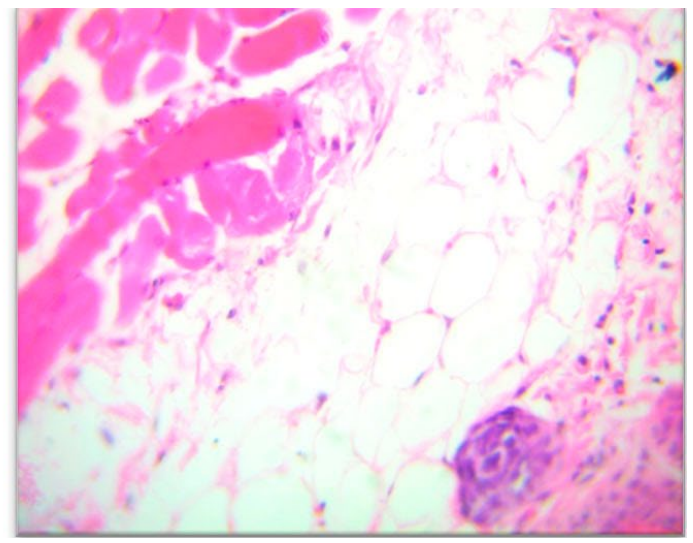

Fig. 10-B. Histological section in Dermis - Hypodermis to the treated area with nanoparticles and Ciprofloxacin. Fat cells

(A) skeletal muscle fibers, (B) Lymphocytic aggregation, (C) (H \& E X 40). 
of epithelium was of 3 layer covered by strands of keratin on its surface The dermis was containing extensive bundles of collagen fibers and fibroblast with presence of lymphocytes and macrophage .The hair follicle and sebecous gland were shown easily in the dermis directed to word the epidermis (Fig 10-A).

The fat cells and skeletal muscle fibers of the deepest layer of dermis and hypodermis were intact and a few number of WBCs, macrophages were note in between (Fig 10-B).

\section{DISCUSSION}

Surgical wound pollutants are likely to create from three main sources: (a) the environment (exogenous bacteria in the air or those introduced by traumatic damage), (b) the surrounding skin (involving members of the normal skin microflora such as S. epidermidis, micrococci, skin diphtheroids and propionibacteria) and (c) endogenous sources connecting mucous membranes (primarily the gastrointestinal, oropharyngeal and genitourinary mucosae) and distant contagious source (subcutaneous abscesses) Endogenous contamination occurs by two routes: by direct establishment from a dirty focus or by metastatic spread from distant foci by either hematogenous or lymphatic routes. The first wound is dirty at the time of cut; the second develops so dirty, over a period of time. In both cases the surgeon is anxious with prevention of infection in wounds adjudged to be clean at the time of closure ${ }^{22}$.

The results of this study showed 50(83.3\%)strain belong Staphylococcus aureus isolated from 60samples taken from Surgical wound contamination. The results of our study agreed with $^{23}$. Out of the 57 isolated from wound contamination after Surgical process, 20 were Gram positive, 29 Gram-negative and 8 anaerobes. Amongst Gram-positive isolated, Staph aureus isolates shown the highest prevalence (28.1\%). Each of B-haemolytic streptococci and actinomycetes had an occurrence of $3.5 \%$. Gram negative isolated from the Enterobacteriaceae family were $26.3 \%, 12$ of them belonging to E. coli, and one to each Kle. pneumoniae, Proteus mirabilis, Citrobacter species. In adding, Pasteurella multocida was found in 12 (21.0\%) isolates and Pseud aeruginosa in $3.5 \%$ of samples.
Obligate anaerobic pathogenic microflora was only represented by the species Prevotella melaninogenica. on other study finding In total, 157 of 203 cases of Surgical site contagions submitted during the study period met the set presence criteria. The remaining 46 samples produced either no growth or only insignificant non-specific growing. In 37 (23\%) of the positive cultures two pathogens were detected, leaving in total 194 pathogenic isolates from the 157 dogs included in the study. Eight different bacterial species were identified in the 194 samples. Staphy pseudintermedius was the most prevalent finding $(46 \%, n=90)$, followed by B-haemolytic Strep. spp. $(24 \%, n=47)$, E. coli $(11 \%, n=21)$ and S.aureus $(8 \%, n=15)$. The remaining pathogenic isolates were Staphylococcus schleiferi coagulans $(4 \%, n=7)$, Pasteurella multocida $(3 \%, n=6), P$. mirabilis $(2 \%, n=4)$ and $P$. aeruginosa $(2 \%, n=4)$. endogenous flora is the main source of bacteria contaminating surgical injuries ${ }^{24}$. The endogenous skin flora is also recognized as an important cause of SSI in dogs, as aseptic grounding of the skin cannot totally eradicate skin-associated microbes, especially not bacteria residing in the deeper parts of the skin such as the hair follicles and sebaceous glands. Both superficial and deeper contamination can be the result, as the bacteria can enter deeper tissues during the initial cut $^{25}$. All the bacteria cultured in the education, including those less commonly linked with skin disease and skin carriage than staphylococci, might be endogenous flora recently transferred to the skin at the incision site through the dogs grooming behaviour, or through pollution of affected tissues during operation ${ }^{26}$.

In this study, all isolated of $S$. aureus showed multi-drug resistant to the commonly arranged antibiotics such as, Trimethoprim/ Sulfamethoxazole, Tetracycline, pencillin, Ciprofloxacin and cephalosporin. leading to treatment failure, economic losses, but also be a source of resistant bacteria/genes (including zoonotic bacteria) that may characterize a risk to human health ${ }^{27}$.

Despite cumulative advances in medical science and the extension of treatment techniques, infectious diseases are still considered as major cause of worldwide deaths ${ }^{28}$. Pathogenic microbes have different ways to deal with antimicrobial 
agents such as antibiotics and indiscriminate uses of these compounds have led to the development of drug resistance. Drug- resistant bacteria, is easily crossed antibiotic treatment and create many clinical problems. Even drug sensitive bacteria that are able to form biofilms, when located in this structure will respond differently to antibiotics ${ }^{29}$.

The results of the current study showed the result of nanoparticles and their capacity to inhibit the growth and killing of antibioticresistant bacterial isolated. The results of our study decided with ${ }^{30}$, Ni nanoparticles in particular have confirmed broad-spectrum antibacterial goods against both Gram-positive and Gramnegative bacteria. e.g Staph. aureus, proteus mirabilis E. coli and Pseudomonas aeruginosa. The antimicrobial machinery of action of NPs is generally described as adhering to one of three models: oxidative stress initiation, metal ion release, or non-oxidative mechanisms. These three types of machines can occur simultaneously. Certain studies have proposed that NiNPs prompt neutralization of the surface electric charge of the bacterial membrane and alteration its penetrability, ultimately leading to bacterial death. Moreover, the generation of reactive oxygen species (ROS) prevents the antioxidant protection system and causes mechanical injury to the cell membrane. According to existing research, the major events underlying the antibacterial effects of NPs are as follows: 1 ) trouble of the bacterial cell membrane; 2 ) generation of ROS; 3 ) diffusion of the bacterial cell membrane; and 4) introduction of intracellular antibacterial effects, including interactions with DNA and proteins .5) the capacity of nickel ferrites to induce gaps and pits which causes the membrane of the bacterium cells to piece.

The method results High resistance degree of antibiotics by Gram-negative bacilli and Gram positive cocci isolated may be due to extensive drug-resistant bacteria or selfmedication $^{31}$. Studied the antibacterial activity of $\mathrm{Ni}$ nanoparticles in mixture with different antibiotics "tetracycline and ciprofloxacin erythromycin and chloramphenicol. Against Gram positive and Gram-negative bacteria "Strepto pneumoniae Staphyl. aureus, Shig. flexneri and Pseudomonas aeruginosa" with inhibition of bacterial biofilm action about $65 \%$.

A current study by ${ }^{32}$, they found synergistic antimicrobial influence of NINPS in mixture with streptomycin and kanamycin, oxytetracycline against Staph .aureus, Escherichia coli Pseudomonas aeruginosa with 80-90\% inhibition of bacterial biofilm creation. In this study, NiNPs showed remarkable antibacterial action against multidrug-resistant Gram-negative and Gram positive bacilli isolated from surgery wound infections, these results are consistent with numerous of studies have documented antibacterial actions of NiNPs against Grampositive and Gram-negative bacterial pathogens with close outcomes of MIC values ${ }^{33}$.

The synergistic anti-bacterial and antibiofilm action between NiNPs and designated antibiotics might be ascribed to different machineries of action of antibiotics and NiNPs effect molecular targets different from selected drugs which including “i) NiNPs enter bacterial cell, denature ribosomes and overpower the expression of enzymes and proteins essential for ATP manufacture, thus leading to cell disruption. ii) NiNPs has also the ability to avoid DNA relaxing by binding to them, hence inhibiting the repetition of bacteria. iii) Targeting the bacterial membrane also leads to dissipation of proton motive force ${ }^{34}$.

\section{ACKNOWLEDGMENTS}

None.

\section{CONFLICT OF INTEREST}

The authors declare that there is no conflict of interest.

\section{FUNDING}

None.

\section{AUTHORS' CONTRIBUTION}

All authors listed have made a substantial, direct and intellectual contribution to the work, and approved it for publication.

\section{DATA AVAILABILITY}

All datasets generated or analyzed during this study are included in the manuscript and/or the Supplementary Files 


\section{ETHICS STATEMENT}

Not applicable.

\section{REFERENCES}

1. Lissovoy G, Fraeman K, Hutchins V, Murphy D, Song D, and Vaughn BB, Surgical site infection: incidence and impact on hospital utilization and treatment costs. Am $J$ Infect Control, 2009; 37(5): 387-397. doi: 10.1016/j. ajic.2008.12.010

2. Owens $C D$, and Stoessel $K$, Surgical site infections: epidemiology, microbiology and prevention. $J$ Hosp Infect., 2008; 70(Suppl 2): 3-10. doi: 10.1016/S01956701(08)60017-1

3. Pradhan GB, and Agrawal J, Comparative study of post operative wound infection following emergency lower segment caesarean section with and without the topical use of fusidic acid. Nepal Med Coll J., 2017; 11(3): 189-91.

4. Ahmed MI, Prevalence of nosocomial wound infection among postoperative patients and antibiotics patterns at teaching hospital in Sudan. N Am J Med Sci., 2012; 4(1): 29-34. doi: 10.4103/1947-2714.92900

5. Mulu W, Kibru G. Beyene G, Damtie M. Postoperative nosocomial infections and antimicrobial resistance patterns of bacterial isolates among patients admitted at FelegeHiwot Referral Hospital, Bahirdar, Ethiopia. Ethiop J Health Sci., 2012; 22(1):7-18.

6. Mundhada AS and Tenpe SA. Study of organisms causing surgical site infections and their antimicrobial susceptibility in a tertiary care Government Hospital. Indian J Pathol Microbiol., 2015; 58(2): 195-200. doi: 10.4103/0377-4929.155313

7. Interventional studies for preventing surgical site infections in sub-Saharan Africa: A systematic review. Int J Surg., 2012; 10(5): 242-249. doi: 10.1016/S01956701(08)60017-1

8. Atiyeh BS, Costagliola M, Hayek SN, Dibo SA, Effect of silver on burn wound infection control and healing: review of the literature. Burns., 2007; 33(2): 139-148 . doi: 10.1016/j.burns.2006.06.010

9. Saha S, Dhanasekaran D, Chandraleka $S$ and Panneerselvam A. "Synthesis, characterization and antimicrobial activity of cobalt metal complex against multi drug resistant bacterial and fungal pathogens," Facta Universitasis: Phys. Chem. Tech., 2009; 7(1): 73-80. doi: 10.2298/FUPCT0901073S

10. Raza MA, Zakia Kanwal Z, Rauf A, Anjum Nasim Sabri AN, Riaz S, and Naseem S. "Size- and Shape-Dependent Antibacterial Studies of Silver Nanoparticles Synthesized by Wet Chemical Routes," Nanomaterials, 2016; 74: 21-22. doi: 10.3390/nano6040074

11. Selvan RK, Augustin CO, Berchmans LJ, Saraswathi R, Combustion synthesis of $\mathrm{CuFe}_{2} \mathrm{O}_{4}$. Research Bulletin, 2013; 38: 41-54. doi: 10.1016/S0025-5408(02)010048

12. Cowan ST, Cowan and Steel's manual for identification of medical bacteria. 2nd edition. Cambridge University press, Cambridge, London.1985; 138-139.

13. Cowan ST, Steel KJ, Cowan and Steel's Manual for the Identification of Medical Bacteria (3rd ed.). Cambridge: Cambridge University Press1993.
14. Winn SD, Allen EW, Janda GW, Koneman A. Koneman's Color atlas and textbook of diagnosticmicrobiology Lippincott Williams\& Philadelphia \& Philadelphia, 2006; 1143.

15. Ryan KJ, and Ray CG. Sherris Medical Microbiology 4th edition. McGraw Hill. ISBN.pp.2004 232-390.

16. Manikanda B, Biomerieux Vitek ${ }^{\circledR} 2$ SYSTEM, Encyclopedia of Rapid Microbiological Methods, 2017; 1-32.

17. French GL. "Bactericidal agents in the treatment of MRSA infections--the potential role of daptomycin". J. Antimicrob. Chemother., 2006; 58(6): 1107-17. doi: 10.1093/jac/dkl393

18. Saginur R, Denis W, Ferris SD, Aaron F, Chan C, Lee K. Multiple combination bactericidal testing of Staphylococcal Biofilms from implant-associated infections. Antimicrobial Agents Chemother, 2006; 50(1): 55-61. doi: 10.1128/AAC.50.1.55-61.2006

19. Lema MW, Brown A \& Calkins JH, A general method for the extraction of DNA from bacteria. Journal of Microbiological Methods, 1994; 19(3): 167-172. doi: 10.1016/0167-7012(94)90066-3

20. Micheline S, Ramella MA, Kroth Caroline $M$, Optimization of Random Amplified Polymorphic DNA protocol for molecular identification of Lophius gastrophysus. Cienc. Tecnol. Aliment., Campinas, 2005; 25(4): 733-735. doi: 10.1590/S010120612005000400017

21. Les $\mathrm{H}$, Shiguo $Z$ and Shannon K. Extraction of Bacterial DNA from Gram-Positive and Gram-Negative Species Quick Extract ${ }^{\mathrm{TM}}$ Bacterial DNA Extraction Kit Volume, 2009; 16-3.

22. Sarrafzadeh-Rezaei F, Yousefbaigi, Gh and Shariati A. An experimental study on surgical wound contamination from distant infective source in rabbitsIranian. Journal of Veterinary Research, 2016; 7(1 Ser. No. 14): 29-38, University of Shiraz.

23 Ulrika W, Bjorn B, Ann-Kristin N, and Bodil Strom H. The distribution of pathogens and their antimicrobial susceptibility patterns among canine surgical wound infections in Sweden in relation to different risk factors. Acta Vet Scand., 2015; 57(1): 11. doi: 10.1186/s13028015-0102-6

24. Nelson LL, Surgical site infections in small animal surgery. Vet Clin North Am Small Anim Pract., 2011; 41(5): 1041-56. doi: 10.1016/j.cvsm.2011.05.010

25. Weese JS, Review of multidrug resistant surgical site infections. Vet Comp Orthop Traumatol., 2008; 21(1): 1-7. doi: 10.3415/VCOT-07-11-0106

26. Weese JS. The canine and feline skin microbiome in health and disease. Vet Dermatol., 2013; 24(1): 137-45. e31. doi: 10.1111/j.1365-3164.2012.01076.x

27. Methicillin-resistant staphylococci (MRS) and extended-spectrum beta-lactamases (ESBL)-producing Enterobacteriaceae in companion animals: nosocomial infections as one reason for the rising prevalence of these potential zoonotic pathogens in clinical samples. Int J Med Microbiol., 2011; 301(8): 635-641. doi: 10.1016/j.ijmm.2011.09.009

28. Wieler LH, Ewers C, Guenther S, Walther B, LubkeBecker A Methicillin-resistant Staphylococcus aureus and Staphylococcus pseudintermedius in veterinary 
medicine. Vet Microbiol., 2010; 140(3-4): 418-429. doi: 10.1016/j.vetmic.2009.01.039

29. Moellering JR, Graybill J, McGowan J, Corey L. Antimicrobial resistance prevention initiative- an update: proceedings of an expert panel on resistance. American Journal of Medicine, 2007; 120(7): 4-25. doi: 10.1016/j.amjmed.2007.04.001

30. Barapatre A, Aadil KR, Jha H. Synergistic antibacterial and antibiofilm activity of Nikles nanoparticles biosynthesized by lignin-degrading fungus. Bioresources and Bioprocessing, 2016; 3(1): 8. doi: 10.1186/s40643-016-0083-y

31. Durairaj R, Amirulhusni AN, Palanisamy NK, Mohd-Zain Z, Ping LJ. Antibacterial effect of silver nanoparticles on multi drug resistant Pseudomonas aeruginosa. World
Acad Sci Eng Technol., 2012; 6: 210-213.

32. Li N, Ma L, Wang J, Zheng L, Liu J, Duan Y, Liu H, Zhao X, Wang $\mathrm{S}$, Wang $\mathrm{H}$, Hong $\mathrm{F} \&$ Xie $\mathrm{Y}$. Interaction between Nano-Anatase TiO2 and Liver DNA from Mice In Vivo. Nanoscale Res. Lett., 2010;5:108-115. doi: 10.1007/ s11671-009-9451-2

33. Casadevall $M$, da Cruz Fresco $P$, \& Kortenkamp A, Chromium (VI) mediated DNA damage: oxidative pathways resulting in formation of DNA breaks and abasic sites. Chemico-Biological Interactions, 1999; 123: 117-132. doi: 10.1016/S0009-2797(99)00128-3

34. Young J, Agashe V, Siegers K \& Hartl F. Pathways of chaperone-mediated protein folding in the cytosol. Nat. Rev. Mol. Cell Biol., 2004; 5: 781-791. doi: 10.1038/nrm1492 